\title{
Magical House
}

\section{Debs Tyler-Bennett}

\author{
Spellbound house, \\ where a woman waits, \\ long fingers gripping gloves. \\ Viewed from her window \\ the darkened garden \\ takes on witch shapes. \\ She wishes a mythic incantation, \\ to change her to a tree. \\ Then she'd wait \\ for her love to pass below, \\ and let \\ leaves like white gloves \\ fall to earth.
}

\section{In Celebration:}

Djuna Barnes (1892-1982).

Renee Vivien (1877-1909).

\section{Note}

Debs Tyler-Bennett was born in Sutton-in-Ashfield in 1963, and now lives in Loughborough. In 1986 she graduated as an MA from SUNY, Brockport and is now studying for a Ph.D. on the life and works of Djuna Barnes, at the University of Leicester. She has had works published in Writing Women and Scarlet Women. 